\title{
THROUGH SCIENTIFIC APPROACH BY USING PROBLEM SOLVING TO IMPROVE MATHEMATICAL UNDERSTANDING ABILITY STUDENTS
}

\author{
Rahman Dani $^{1}$, Ayi Solehudin ${ }^{2}$, Rudy Kurniawan ${ }^{3}$ \\ ${ }^{1,2,3}$ Mathematics Education Program Post Graduate IKIP Siliwangi, Cimahi \\ rahmandani371@gmail.com ${ }^{1}$, asolehudin61@ gmail.com ${ }^{2}, \underline{\text { krudy@yahoo.com }}$
}

Received: Nov 12 ${ }^{\text {th }}, 2018$; Accepted: Nov $26^{\text {th }}, 2018$

\begin{abstract}
This research is a research through a scientific approach by using problem solving to improve the understanding of mathematical abilities of vocational students. This research is a quasi-experimental form the which aims to test the achievement and improvement of students' understanding of mathematical skills through a scientific approach, using problem solving rather than learning that only uses a scientific approach. And examine the implementation of learning steps through a scientific approach, using problem solving. The population in this study were all students of class X Vocational School in Bandung Regency, while the sample was class X students from one of the Vocational Schools roomates were determined purposively and were randomly selected from the existing class X. Based on the results of the data analysis, it was concluded that the achievement and improvement of the understanding of mathematical abilities of Vocational students who learning obtained through the scientific approach, using problem solving was better than reviews those who obtained using the scientific approach learning only. And the implementation of learning through a scientific approach, using problem solving is Carried out in accordance with the planned learning steps
\end{abstract}

Keywords: Scientific Aproach, Problem Solving, Mathematic Understanding

\begin{abstract}
Abstrak
Penelitian ini merupakan penelitian melalui pendekatan saintifik dengan menggunakan pemecahan masalah untuk meningkatkan pemahaman kemampuan matematika siswa SMK. Penelitian ini adalah bentuk eksperimen semu yang bertujuan untuk menguji pencapaian dan peningkatan pemahaman siswa tentang keterampilan matematika melalui pendekatan saintifik, menggunakan pemecahan masalah daripada pembelajaran yang hanya menggunakan pendekatan saintifik. Dan memeriksa implementasi langkah-langkah pembelajaran melalui pendekatan saintifik, menggunakan pemecahan masalah. Populasi dalam penelitian ini adalah semua siswa sekolah kejuruan kelas X di Kabupaten Bandung, sedangkan sampelnya adalah siswa kelas $\mathrm{X}$ dari salah satu ruangan sekolah kejuruan ditentukan secara purposive dan dipilih secara acak dari kelas $\mathrm{X}$ yang ada. Berdasarkan hasil dari analisis data, disimpulkan bahwa pencapaian dan peningkatan pemahaman kemampuan matematika siswa Vokasi yang belajar Diperoleh melalui pendekatan ilmiah, menggunakan pemecahan masalah lebih baik daripada Ulasan mereka yang Diperoleh hanya menggunakan pendekatan pembelajaran saintifik saja. Dan pelaksanaan pembelajaran melalui pendekatan ilmiah, menggunakan pemecahan masalah dilakukan sesuai dengan langkah-langkah pembelajaran yang direncanakan.
\end{abstract}

Kata Kunci: Pendekatan Saintifik, Pemecahan Masalah, Pemahaman Matematik

How to Cite: Dani, Rahman., Solehudin, Ayi., \& Kurniawan, Rudy. (2018). Through A Scientific Approach by Using Problem Solving to Improve The Ability of Mathematical Understanding of Vocanational Students. JIML, 1 (4), 350-360. 


\section{INTRODUCTION}

In the process of learning mathematics, mathematical understanding is a very important part (Destiniar, 2016; Fariana, 2017; Purnamasari \& Herman, 2016; Suhandri, 2016).Mathematical understanding is an important foundation for ways of thinking in solving a mathematical problem and problems in everyday life. According to Soejadi so that mathematics learning is more meaningful, it is necessary to pay attention to learning objectives that are "formal" and goals that are "material". Formal objectives emphasize more on "structuring reasoning and determining student personality". Material goals emphasize "mathematical understanding skills related to mastery of problem solving and the application of mathematics.(Destiniar, 2016). The importance of problem solving can be felt not only for those who study mathematics, but also those who will apply it to other fields of study in daily life (Hajar \& Sari, 2018).

According Soemarmo, to grasp an object in depth one must know: "the object itself, its relationship with other similar objects, relationships with other objects that are not similar, dual relationships with similar objects and objects in relation to other theories" (Yunita, 2003), understanding the fundamental aspects of learning, so that the model study should include the subject matter of understanding (Kesumawati, 2012), In line with the opinions Hewson and Thorleyn that understanding is a concept that can be digested by the students so that students understand what it meant, was able to find a way to express these conceptions, as well as to explore the possibilities associated (Alan \& Afriansyah, 2017),

In fact, in the field of understanding students' mathematical ability is still low. This is supported by findings Henningsen and Stein 1997; Peterson 1998; Mullis, et al showed that the learning of mathematics in general are still focused on the development of thinking skills lower stage of a procedural nature. To improve students' mathematical understanding, we need an approach and learning model that can support the implementation of learning that puts students as a subject of study. One approach that can be used is through a scientific approach to the use of problem solving.

Scientific approach to make learning more active and not boring, students can construct their knowledge and skills through the facts found in the investigation on the field to learning(Ine, 2015), In addition, with this scientific approach based learning, students are encouraged better able to observe, question, reason, and communicate or present things that are learned from direct experience, or natural phenomena (Ine, 2015), The learning process on a scientific approach of this research is to observe, ask, collect data, associate and communicate. While problem solving isan approach to student-centered learning and drip emphasis on the provision of a problem by the teacher to the student. To help solve the problem given the student can follow the steps that understand the problems, plan solutions, solve the problem according to plan and check back

The scientific approach to the use of problem solving is a learning process that is more emphasis on the discovery of concepts and solve problems that encourage students to develop the ability to think. The principal advantage through a scientific approach to problem solving manggunakan is to train students' thinking skills, analyze a problem and engage students actively in the process of learning to mermuskan settlement activities in solving a problem. 
352 Dani, Solehudin \& Kurniawan, Through A Scientific Approach by Using Problem Solving to Improve The Ability of Mathematical Understanding of Vocanational Students

By using a problem solving approach, student learning interest will increase when students follow learning according to the steps of the problem solving approach (Hendriana \& Fadhillah, 2019). The purpose of this study was to determine the attainment and increase the ability of students learning mathematical understanding through scientific approach to problem solving using any better than that using only scientific approach.

\section{METHOD}

The method in this study using a quasi-experimental method of research that is used to look for the effect of treatment specific. In this case study to the group treated through a scientific approach to problem solving using the so-called experimental group and used as a comparison control group using only scientific approach. Before and after treatment the same class are given tests that test the ability of mathematical understanding.

The population in this study were all students of class X SMK in Bandung. With the subject sample is one of the SMK in Bandung regency, while the sample randomly selected two classes where the experimental class learning gained through using the scientific approach problem solving, and gain control class scientific learning course. The determination of the sample with purposive manner. According Sundjana (Aesih, 2015) suggests that the purposive sample (sample consideration) occurs when sampling is carried out based on individual considerations or considerations of researchers. Purposive sampling is generally based more on considerations of researchers, the certainty of existing or erratic deployment ..

Before getting treatment, the first two classes were given the initial test (pretest) with the aim to determine the beginning of understanding mathematical ability of students prior to treatment. Meanwhile, after getting second class treatment given final test (post-test) with the aim of understanding the mathematical abilities of vocational students in the experimental class is better than the control class. The instrument used was a set of tests in the form of matter in the form description consists of 5 questions test the ability of mathematical understanding. Prior to the test the ability of understanding mathematical done, first tested the validity, reliability, difficulty index and distinguishing features of the test instrument. Test the validity of using the formula Product Moment correlation and reliability testing with Alpha formula.

Examples of test capabilities mathematical understanding trigonometry vocational material in this study are as follows:

1. Indicators: Explain the concept is true and correct

Question:

An angled triangle one corner of 300 and a length of one side of $12 \mathrm{~cm}$. According to the picture below: $\sqrt{3}$

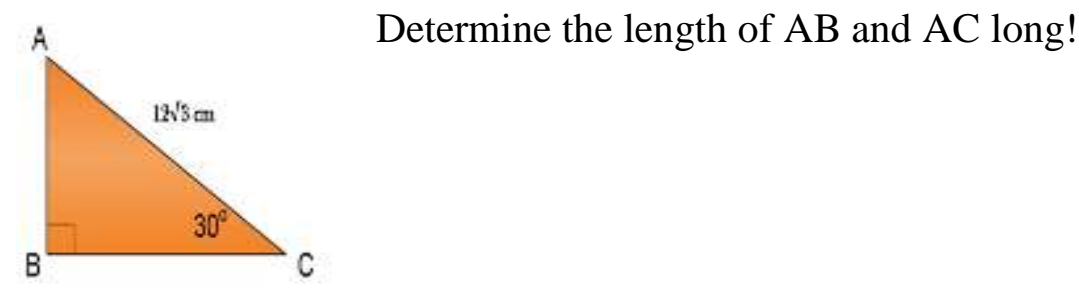

2. Indicators: Applying mathematical concepts correctly and appropriately 
Question:

$\mathrm{K}$ and 1 intersecting street in town A. Department of urban spatial want to connect the town $\mathrm{B}$ to town $\mathrm{C}$ m building roads and cut off both roads. If the distance between town $\mathrm{A}$ and town $\mathrm{C}$ is $5 \mathrm{~km}$, the angle formed by the path $\mathrm{m} 1$ is $45^{\circ}$ and the angle formed roads and road $\mathrm{k} \mathrm{m}$ is $30^{\circ}$. The illustration on the right and then specify a distance of city A and city B!

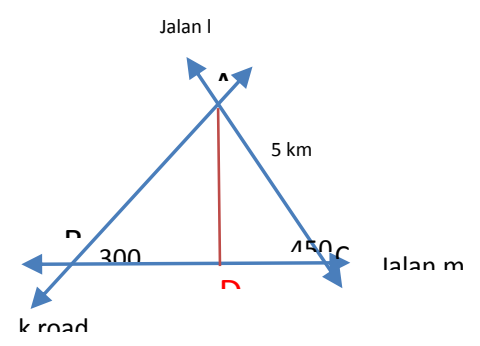

\section{RESULTS AND DISCUSSION}

\section{Results}

Based on data processing, ata obtained from this research is quantitative data that is data pretest, posttest, and $\mathrm{n}$ - normalized gain understanding of mathematical abilities of students in the experimental class and control class. To determine the ability of understanding mathematical achievement between students in the experimental class and control class is calculated based on the posttest scores. To determine the increase in the ability of mathematical understanding between students in the experimental class and control class is calculated based on n-gain normalization.

Prior to the analysis will be presented first descriptive comprehension ability scores from pretest, posttest, and $\mathrm{N}$ - Gain in the following Table:

Table 1. Understanding of Mathematical Ability Test Results

\begin{tabular}{ccccccccc}
\hline \multirow{2}{*}{ class Research } & \multicolumn{3}{c}{ pretest } & \multicolumn{3}{c}{ Postes } & \multicolumn{2}{c}{$\mathrm{N}$ - Gain } \\
\cline { 2 - 9 } & $\overline{\mathrm{x}}$ & SD & SMI & $\overline{\mathrm{x}}$ & SD & SMI & $\overline{\mathrm{x}}$ & SD \\
\hline Experiment & 7,29 & 2.36 & 26 & 20.31 & 2.14 & 26 & .69 & .60 \\
Control & 7.31 & 1.86 & 26 & 18.66 & 2.07 & 26 & .12 & .11 \\
\hline
\end{tabular}

Based on Table 1 above, shows that the average scores of initial tests the ability of the experimental mathematical understanding graders is 7.29 while the average score of 7.31 in the control class. The only difference is around .02 , this shows that the difference in the average classroom experiment with control class is very small and can be concluded that the initial capabilities mathematical understanding of both classes is not much different. After learning, the ability of mathematical understanding experimental class is better than the control class means increased ability mathematical understanding through scientific approach to problem solving using any better than that using only saintifk approach.

In the initial test data analysis (pretest), after the normality test showed that the experimental class significance value .036 and .295 significance value control class experimental class is not normal because of the significance of less than .05 while the control class significance greater than .05 so the data distribution normal. Because one of the data are not normally distributed, then it does not meet the criteria for parametric statistical tests so that further nonparametric statistics Mann-Whitney U-test equality of two average - average by using SPSS 23.0 for Windows, the results are as follows: 
354 Dani, Solehudin \& Kurniawan, Through A Scientific Approach by Using Problem

Solving to Improve The Ability of Mathematical Understanding of Vocanational Students

Table 2. Two Significant Test Results Similarity Score average pretest

\begin{tabular}{ccccc}
\hline $\begin{array}{c}\text { class } \\
\text { Research }\end{array}$ & $\mathrm{N}$ & Mann-Whitney $U$ & Sig. & Interpretation \\
\hline $\begin{array}{c}\text { Experiment } \\
\text { Control }\end{array}$ & 35 & 605.000 & .929 & H0 Accepted \\
\hline
\end{tabular}

Based on Table 2 is obtained from the average of test results using the Mann-Whitney obtained Sig. (2-tailed) in the pretest score mathematical comprehension ability is .929> 05 . This shows that H0. This means that there is no difference prior knowledge of mathematical understanding of vocational students significantly between learning through using the scientific approach to problem solving learning to use the scientific approach alone.

To determine whether there is the achievement of students' mathematical understanding capabilities, performed data analysis postes. Below is a table of test results of normality and homogeneity of data post-test using SPSS 23.0 software for Windows.

Table 3. Normality and Homogeneity Test Result Data Postes

\begin{tabular}{ccccccc}
\hline \multirow{2}{*}{ type Test } & \multicolumn{3}{c}{ class Experiment } & \multicolumn{3}{c}{ classroom Control } \\
& statistic & df & Sig. & statistic & Df & Sig. \\
\hline \multirow{2}{*}{ Normality } & .969 & 35 & 0,407 & .957 & 35 & .189 \\
& \multicolumn{4}{c}{ Normal } \\
Levene Statistic $=.128$ \\
homogeneity \\
\multicolumn{5}{c}{ Sig. $=.722$} \\
Homogeneous \\
\hline
\end{tabular}

Based on Table 3 normality test significance value of the experimental class is .407 and the significance of the control class is .189, where both classes have a sig. $>.05$ so H0. This means that the data sample posttest in the experimental class and control class normal distribution. Then test the homogeneity of variance using Levene test test Statistics on the posttest. In Table 3 obtained significant value homogeneity of variance is .722, which means two sample groups are homogeneous.

Furthermore, the significant difference test of two average post-test capability mathematical understanding by using t-test of the party that is testing the right side by using the Independent Sample t-test assuming both homogeneous variance (equal variance assumed) with a significance level of .05 . In this case the researchers used a test right parties in order to determine which one is better learning. The test criteria are as follows:

If the value of Sig. $(1-$ tailed $)>.05$ then $\mathrm{H}_{0}$ is accepted.

If the value of Sig. $(1-$ tailed $) \leq .05$ then $\mathrm{H}_{0}$ is rejected.

After testing the difference between two average postes ability mathematical understanding by using SPSS 23.0 for Windows, then the results are as follows: 
Table 4. Test Results Significant Difference Two average score Postes

\begin{tabular}{cccc}
\hline \multicolumn{3}{c}{ t-test for Equality of Means } & \\
\cline { 1 - 3 } $\mathrm{T}$ & Df & Sig. (2-tailed) & Conclusion \\
3.260 & 68 & .002 & $\mathrm{H}_{0}$ is rejected \\
\hline
\end{tabular}

Based on the results in Table 4 shows that the value sig (2 - tailed) was .002. "Due to test hypotheses of the parties (one-tailed) then sig. (2-tailed) should be halved "(Uyanto, 2009), By looking at the table above, sig. (1 - tailed) was. Because sig. (1-tailed) $<.05$ then $\mathrm{H} 0$ is rejected. Thus it can be concluded that there are achievement ability of students learning mathematical understanding through scientific approach to problem solving using any better than that using only scientific approach. $\frac{.002}{2}=.001$

$\mathrm{N}$ data analysis-normalized gain conducted to determine the mathematical connection between the increased capacity through the scientific approach to problem solving using the scientific approach that uses only. Here is a table of test results of normality and homogeneity index of $\mathrm{n}$ - normalized gain by usingsoftware SPSS 20.0 for Windows obtained the following results:

Table 5. Normality and Homogeneity Test Result Data Index N - Gain normalized

\begin{tabular}{ccccccc}
\hline \multirow{2}{*}{ type Test } & \multicolumn{3}{c}{ class Experiment } & \multicolumn{3}{c}{ classroom Control } \\
& statistic & df & Sig. & statistic & df & Sig. \\
\hline \multirow{2}{*}{ Normality } & .973 & 35 & .530 & .980 & 35 & .768 \\
& \multicolumn{4}{c}{ Normal } \\
Levene Statistic $=.009$ \\
homogeneity
\end{tabular}

Based on Table 5 significance value of the experimental class is .530 and the significance of the control class is .768 , where both classes have a sig. $>.05$ so H0. This means that the two samples come from populations with normal distribution. Furthermore, the homogeneity test to determine whether the variants of samples analyzed data from homogeneous or not. The significance of homogeneity is .936 , which sig. $>.05$ so H0. Thus, variants of the experimental class and control class berhomogen. Since both classes and the normal distribution has a homogeneous variant, then performed two different test average. After testing the difference between two average postes ability mathematical understanding by using SPSS 23.0 for Windows, then the results are as follows:

Table 6. Test Results Significant Difference Two Average Index Data N - Gain normalized

\begin{tabular}{cccc}
\hline \multicolumn{3}{c}{ t-test for Equality of Means } & \\
\cline { 1 - 3 } $\mathrm{T}$ & Df & Sig. (2-tailed) & Conclusion \\
3.084 & 68 & .003 & $\mathrm{H}_{0}$ is rejected \\
\hline
\end{tabular}

Based on the results in Table 6 shows that the value sig (2-tailed) was .003 then sig. (1 tailed) was. Because sig. (1-tailed) $<0.05$ then $\mathrm{H}_{0}$ is rejected. It can be concluded that there is 
an increasing understanding of mathematical ability of students learning through scientific approach to problem solving using any better than that using only scientific approach $\frac{.003}{2}=.0015$

The following are the difficulties - difficulties experienced by the experimental class students in solving mathematical understanding capabilities in a matter of numbers 2 and 4 are presented below:

1. On the matter of the second indicator is to understand the concept correctly as much as 8 students can answer correctly, the algorithm is complete, and precise in using the concept to the questions. A total of 24 students responded less precise but there was little miscalculation, complete algorithms, and the use of the concept of mostly right. 3 students responded quite right there are many calculation errors, the algorithm is not complete and accurate. The results of the analysis of the experimental class difficulty on this indicator can be seen in Figure 1

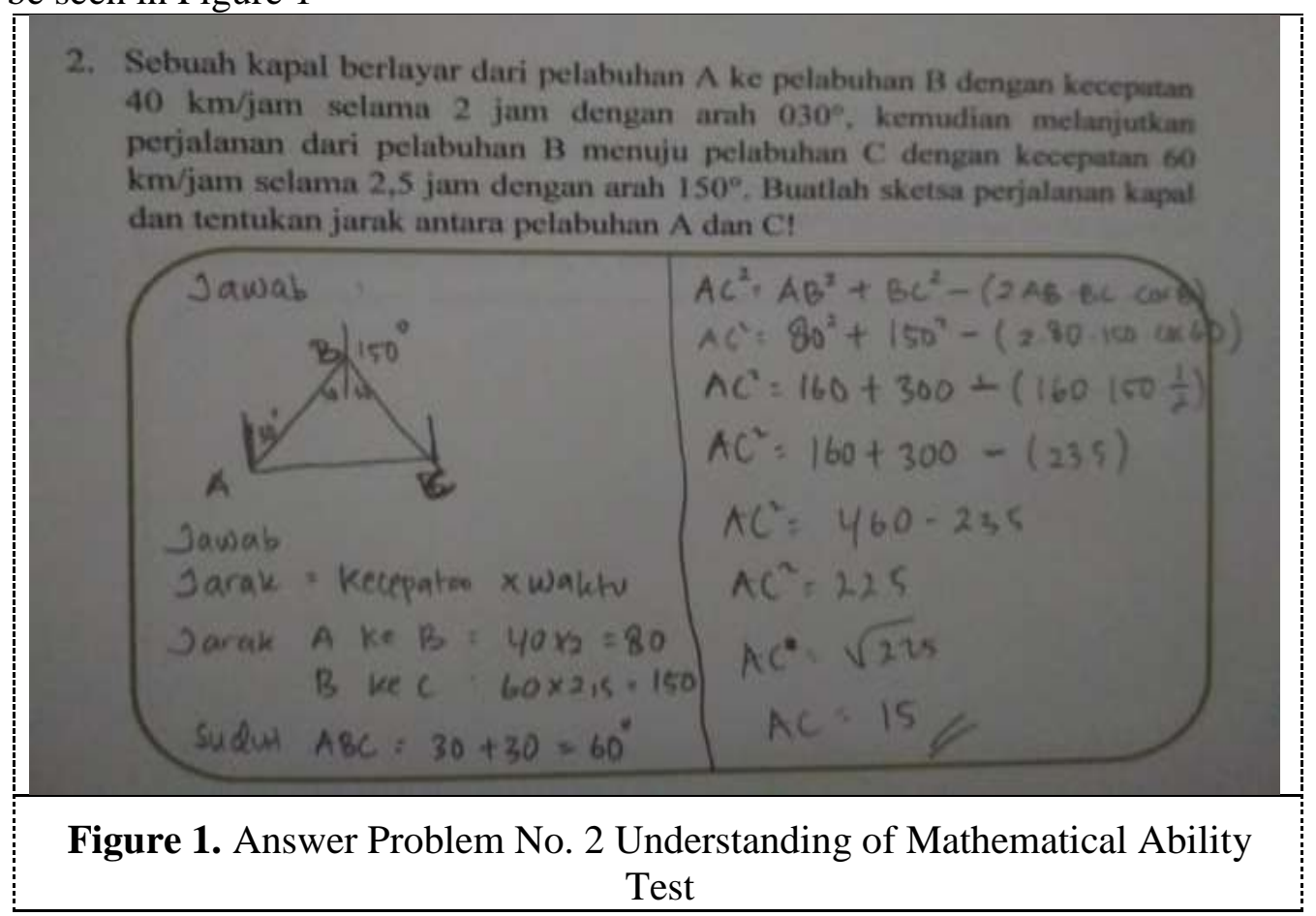

Figure 1 above the students can be seen that students are less rigorous in analyzing the answer so the answer is not quite right.

2. On the matter of number four indicators that appropriately apply the concept as much as 8 students can answer correctly, the algorithm is complete, and precise in using the concept to the questions. A total of 24 students responded less precise but there was little miscalculation, complete algorithms, and the use of the concept of mostly right. 3 students responded quite right there are many calculation errors, the algorithm is not complete and accurate. The results of the analysis of the experimental class difficulty on this indicator can be seen in Figure 2 


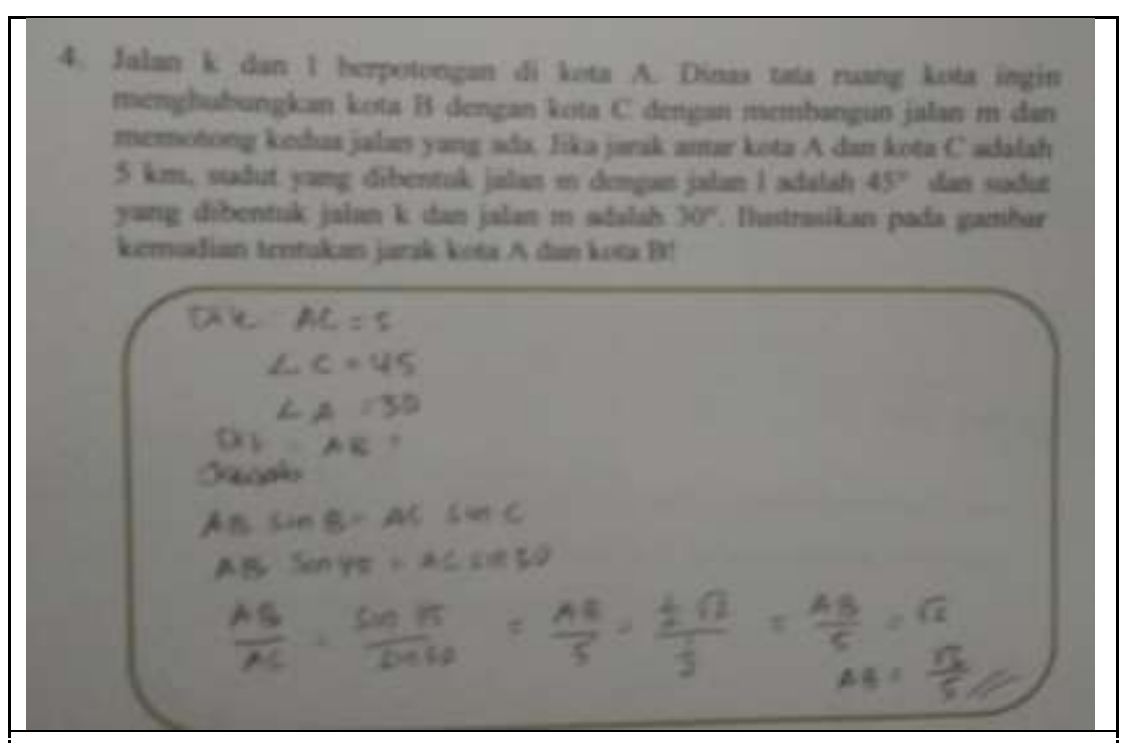

Figure 2. Answer Problem No. 4 Comprehension Ability Test

Figure 2 above shows that the students are less careful in analyzing the problem so that the answer is still not quite right.

The following is a recapitulation of the difficulties experienced by the experimental class students in solving ability of students' mathematical understanding provided in Table 7 below:

Table 7. Difficulties recapitulation Problem Solving Ability Students in Grades Math Understanding Experiment

\begin{tabular}{|c|c|c|c|c|c|c|c|c|c|}
\hline \multirow[t]{2}{*}{ Indicator } & \multirow[t]{2}{*}{ Question } & \multicolumn{2}{|c|}{$\begin{array}{c}\text { Right } \\
\text { answers }\end{array}$} & \multicolumn{2}{|c|}{$\begin{array}{l}\text { Answer } \\
\text { Less } \\
\text { Right, But } \\
\text { Bit Error } \\
\text { Loading }\end{array}$} & \multicolumn{2}{|c|}{$\begin{array}{l}\text { Answer } \\
\text { Less } \\
\text { Exactly, } \\
\text { Loading } \\
\text { Many } \\
\text { Errors }\end{array}$} & \multicolumn{2}{|c|}{$\begin{array}{c}\text { No } \\
\text { answer }\end{array}$} \\
\hline & & Tot & $\%$ & Tot & $\%$ & Tot & $\%$ & Tot & $\%$ \\
\hline $\begin{array}{c}\text { Explaining } \\
\text { the concept } \\
\text { is true and } \\
\text { correct }\end{array}$ & 1 & 15 & 42.86 & 18 & 51.43 & 2 & 5.71 & 0 & 0 \\
\hline $\begin{array}{l}\text { Understand } \\
\text { the concept }\end{array}$ & 2 & 8 & 22.86 & 24 & 68.57 & 3 & $8: 57$ & 0 & 0 \\
\hline correctly & 3 & 9 & 25.71 & 17 & 48.57 & 9 & 25.71 & 0 & 0 \\
\hline $\begin{array}{l}\text { Applying the } \\
\text { concept } \\
\text { appropriately }\end{array}$ & 4 & 8 & 22.86 & 24 & 68.57 & 3 & $8: 57$ & 0 & 0 \\
\hline $\begin{array}{c}\text { Giving an } \\
\text { example of a } \\
\text { concept } \\
\text { appropriately }\end{array}$ & 5 & 5 & $14: 29$ & 24 & 68.57 & 6 & $17: 14$ & 0 & 0 \\
\hline
\end{tabular}


Table 7 above it can be seen the number of students who can solve problems by answering the ability of mathematical understanding correctly, less precise answer contains fewer errors, less precise answer contains many errors and did not answer the experimental class.

\section{Discussion}

Learning activities performed 10 times with the study (treatment) which is different that the experimental class by using the scientific approach problem solving and the control class using only scientific approach. Learning to do as much as 8 times, 1 meetings to pre-test the ability of mathematical understanding, one more meeting for the post-test capability mathematical understanding.

Based on the above data processing show that: (1) the achievement of mathematical understanding and capacity of vocational students whose learning through using a scientific approachproblem solving compared to using only a scientific approach; (2) difficulty difficulty in solving students - about mathematical understanding ..

The results of data processing showed that Ho is rejected on achievements and upgrades mathematical understanding between students in the experimental class and control class, indicating that through a scientific approach to the use of problem solving significantly influence the upgrading mathematical understandingstudents. It can be concluded that the ability to connect students who get teaching mathematicsthrough a scientific approach to the use of problem solving significantly better than students who received any study with scientific approach.

These results are consistent with other researchers who claimed that the various advantages of the approach to scientific is to make the student who told a student who is looking out, from a teacher who is a source of learning to be learned from a variety of sources, from textual approach to the process as strengthening the use scientific approach, of learning that emphasizes the single answer to the truth of learning with multi-dimensional response, prioritizing learning cultivation and empowerment of students as lifelong learners (Ine, 2015).

Implementation steps - step learning through scientific approach by using problem solving can be done in accordance with the theory. The first step is to pray then apersepsi, the researcher as a teacher presents a problem in the process of early learning activities to students. Permasalahanya shape as students observe images contained on a worksheet (LKS) or by drawing on the blackboard presented by the teacher. This step was the first phase of scientific: to observe. Viewing a problem that has been presented by the teacher. The second stage is routed ask students to ask questions that are not understood from what was observed. This activity aims to develop creativity, curiosity, the ability to formulate questions to establish the critical thinking necessary for intelligent life and lifelong learning. The third phase students are given the freedom to gather as much related material to be covered, the source can be from books, the Internet and others. The fourth stage students discuss complete settlement of existing problems on a worksheet. Based on observations of researchers in the field, at this step the students practice for their own self and find the desired mathematical concepts in the problems posed. The last stage Students present their thoughts in the form of conclusions based on the discussion group to develop an attitude of honest, conscientious, tolerance, the ability to think systematically, to express their opinions politely. Students present the results of group discussion in the classical style. Students express an opinion on the presentation made. Other students comment on the presentations made and the other 
students were given the opportunity to answer it. This is in line with Mahmudah, Fadhillah, \& Kurniawan (2019) opinion that learning using a scientific approach can challenge students 'ability to develop students' thinking skills in finding mathematical answers/formulas/ concepts.

\section{CONCLUSION}

Based on data analysis and discussion of the research concluded that the ability to connect mathematics students whose learning approach to scientific by using problem solving significantly better than the approach scientific course with a significance level of 5\%, and the difficulties - difficulties experienced by students in solving problems - problems mathematical understanding the experimental class that is located in the indicator to understand the concept correctly and appropriately apply the concept

\section{ACKNOWLEDGMENTS}

Thanks to Mrs. Principal SMK Ma'arif Integrated Cicalengka who have given permission to the researchers to conduct research at the school. Thanks to Mr. Rudy Kurniawan as Lecturer Mathematics Education Master who has guided in doing this research. Thanks to the parties those who have helped in conducting this research.

\section{REFERENCES}

Aesih, C. (2015). Meningkatkan Kemampuan Komunikasi Dan Pemahaman Matematik Serta Minat Membaca Siswa SMP Melalui Penerapan Strategi SQJR. STKIP Siliwangi Bandung.

Alan, U. F., \& Afriansyah, E. A. (2017). Kemampuan Pemahaman Matematis Siswa melalui Model Pembelajaran Auditory Intellectualu Repetition dan Problem Based Learning. Jurnal Pendidikan Matematika, 11(1), 68-77.

Destiniar. (2016). Pengaruh Media Pembelajaran Adobe Flash Player dan Infokus terhadap Pemahaman Konsep Matematis Siswa Kelas VII SMP PGRI 11 Palembang. JPPM, 9(2), 277-282.

Fariana, M. (2017). Implementasi Model Problem Based Learning untuk Meningkatkan Pemahaman Konsep dan Aktivitas Siswa. Journal of Mathematics Education IKIP Veteran Semarang, 1(1), 25-33.

Hajar, Y., \& Sari, V. T. A. (2018). Analisis Kemampuan Pemecahan Masalah Siswa SMK Ditinjau dari Disposisi Matematis. Jurnal Inovasi Pendidikan Dan Pembelajaran Matematika, 4(2), 120-131.

Hendriana, H., \& Fadhillah, F. M. (2019). The Students' Mathematical Creative Thinking Ability of Junior High School Through Problem-Solving Approach. Infinity Journal, $8(1), 11-18$.

Ine, M. E. (2015). Penerapan Pendekatan Scientific Untukmeningkatkan Prestasi Belajar Siswa Padamata Pelajaran Ekonomi Pokok Bahasan Pasar. In Prosiding Seminar Nasional (pp. 269-285). 
360 Dani, Solehudin \& Kurniawan, Through A Scientific Approach by Using Problem

Solving to Improve The Ability of Mathematical Understanding of Vocanational Students

Kesumawati, N. (2012). Meningkatkan Kemampuan Pemahaman Matematis Siswa SMP melalui Pendekatan Matematik Realistik Indonesia (PMRI). Jurnal Pendidikan Matematika, 6(2), 30-44.

Mahmudah, R., Fadhillah, F. M., \& Kurniawan, R. (2019). The Mathematical Connection Ability of Junior Student' S Through The Scientific Approach and Guided Inquiry Method. Jurnal Innovative Mathematics Learning, 2(2), 53-64.

Purnamasari, S., \& Herman, T. (2016). Penggunaan Multimedia Interaktif terhadap Peningkatan Kemampuan Pemahaman dan Komunikasi Matematis, serta Kemandirian Belajar Siswa. EduHumaniora: Jurnal Pendidikan Dasar, 8(2), 178-185.

Suhandri. (2016). Meningkatkan Kemampuan Pemahaman Matematis Siswa SMP/MTs dengan Menggunakan Strategi Konflik Kognitif. JPPM, 9(2), 240-249.

Uyanto, S. S. (2009). Pedoman Analisis Data dengan SPSS Edisi 3 (3rd ed.). Yogyakarta: Graha Ilmu.

Yunita, A. (2003). Pengaruh Metode Stratagem melalui Pembelajaran Kooperatif terhadap Pemahaman Konsep Matematis Siswa Kelas VIII SMP Negeri 20 Padang. Ta' Dib, 17(1), 25-36. 